\title{
COMMUNITY POLICING AS PUBLIC PARTICIPATION STRATEGY FOR ENHANCING SECURITY IN KENYA
}

\author{
David M Kungu' ${ }^{1}$, Stanley Kipsang ${ }^{2}$, Risper Omari ${ }^{3}$ and Doreen Nandwa ${ }^{4}$ \\ Contact-swmwangi2006@yahoo.com \\ 1. Development Studies Department, School of Human Resource Development, Moi University \\ 2. Development Studies Department, School of Human Resource Development, Moi University
}

3. Development Studies Department, School of Human Resource Development, University of Eldoret

4. Development Studies Department, School of Human Resource Development, Moi University

\begin{abstract}
Security is a basic necessity in every society as it is a watershed for development and prosperity in all sectors of the economy. However, for a long time this has been elusive both in the urban and rural areas. The insecurity experienced in many societies ranging from terrorism, cattle rustling to petty crimes has had devastating effects inducing loss of lives and massive destruction of property. In managing the security situation, the police resources in terms of personnel and equipment seem to have been strained as insecurity levels soar. It is believed that the criminals and perpetrators of insecurity live within same society and therefore, members of the society can identify them thus community policing was muted in Kenya. This study therefore, aimed at evaluating community policing as a security enhancing strategy. The study was guided by the Abraham Maslow's hierarchy of needs which identifies security as a great concern which must be satisfied. The study adopted a case study research design with Koibatek District as the case. The target population for the study was 1679 members of community policing at the sub-location, location and Division levels, from which a sample of 265 was picked using stratified sampling, purposive sampling and simple random sampling. Data was collected using questionnaires and interviews and analysed descriptively where percentages and frequencies were computed and presented in tables, pie charts and graphs. The study established that there are community policing structures which have been clearly laid down at all levels as per the community policing manual. Further, community policing plays a significant role in reducing crime though riddled by a number of challenges such as mistrust and lack of capacity to handle crime. The study recommends that a strong partnership be created between the police and the members of the public and that capacity building through training is required to make the community policing committees effective.
\end{abstract}

Key Terms: Community Policing, Public Participation, Security, Insecurity, Security Strategy

\section{Council for Innovative Research}

Peer Review Research Publishing System

Journal: Journal of Social Sciences Research

Vol. 7, No.3

jssreditor.cir@gmail.com

www.jssronline.com

$1411 \mid \mathrm{P}$ a g e

M a y 16,2015 


\section{INTRODUCTION}

According to the Community Policing Manual (2004), Community Policing as a security strategy in Kenya was launched on the $27^{\text {th }}$ of April 2004 at the Ruai Police station in Nairobi by the then President of the Republic of Kenya with the main objective of having a safe and secure environment for sustained socio-economic development and as part of the Kenya Police Force reforms. This was meant to reduce crime as it was assumed that criminals lived in the community and therefore community members were in a good position to identify them and report them to the police.

The main stakeholders in this strategy are the community/wananchi supported by the Police, the Provincial Administration, and other Stakeholders in the security realm. To meet the intended purpose, committees were established from village to District levels to ensure the success of this strategy

Before its inception, there was conventional policing on one hand which relied heavily on centralized safety and security management which isolated the police from communities they served. On the other hand were the vigilante groups which purported to provide security to the community members at a fee and which mostly took the law into their hands. Therefore, Community Policing was meant to bring a partnership between the community and police in combating crime in the country. It is on this backdrop that this paper focuses on analyzing the effectiveness of Community Policing in curbing crime in Kenya.

\section{Statement of the Problem}

Security has been considered as a key pillar to socio-economic development and prosperity in every society. However, in Kenya this has become elusive as insecurity is on the increase thus negating the spirit of the development process and attainment of millennium development goals and vision 2030 both in the urban and rural areas. The situation is further compounded by the fact that the country does not meet the United Nations requirement of "one police officer for every four hundred and fifty people" (www.wiki/Community Policing.org), as the ratio of the police to the population stands at a low level of one police officer for every one thousand one hundred and fifty Kenyans (Kenya Police annual report 2014). Owing to this limitation, the Government of Kenya was prompted to implement community policing as a measure of reducing the gap between the police and the community to curb insecurity.

In Koibatek District, the security situation has over time deteriorated. It is characterized by theft of livestock and farm produces which has given rise to inter-ethnic conflict. Therefore the objective of this paper is to use the existing information to analyze and document the effectiveness of community policing as a security strategy in Kenya with Koibatek District being the case under study.

\section{Significance of the Study}

The findings of this study will help the Kenyan Government to assess the performance of a strategy it muted to solve the security problems facing the country. This will be achieved by identifying the contributions of the strategy to enhancing the security in the country.

The community in general will also to benefit from the findings of this study as members will understand their role and contribution in community policing and improving their own security. This will also help eliminate the misconception about the intention of community policing as the concept has not been fully grasped by the common man in the country.

In addition, the findings of this study will add to the existing poll of knowledge and also form a basis for further research.

\section{Study Area}

Koibatek District is one of Kenya's administrative Districts lies in Baringo County of the Rift Valley province. It covers an area of approximately 478.2 square kilometres and according to the 2009 census, it has a population of 165,000 persons (KNBS 2010). Administratively, the District is divided into 8 administrative divisions; Mumberes, Torongo, Eldama Ravine, Esageri, Mogotio, Kisanana, Emining, and Sirwa/ Kimngorom Divisions, 48 administrative locations and 90 sub-locations. The district has 1 police division and 4 police stations and 8 administration police divisional stations. Major stakeholders in the community policing strategy in this district include the Administration Police, Kenya Police, Chiefs, Assistant Chiefs, Village Elders and members of the public. Furthermore, there is the District security intelligence committee and below it is the sub-District Security Intelligence Committee. The Sub-District Security Intelligence Committee directly oversees Community Policing and reports to the District Security Intelligence Committee. 


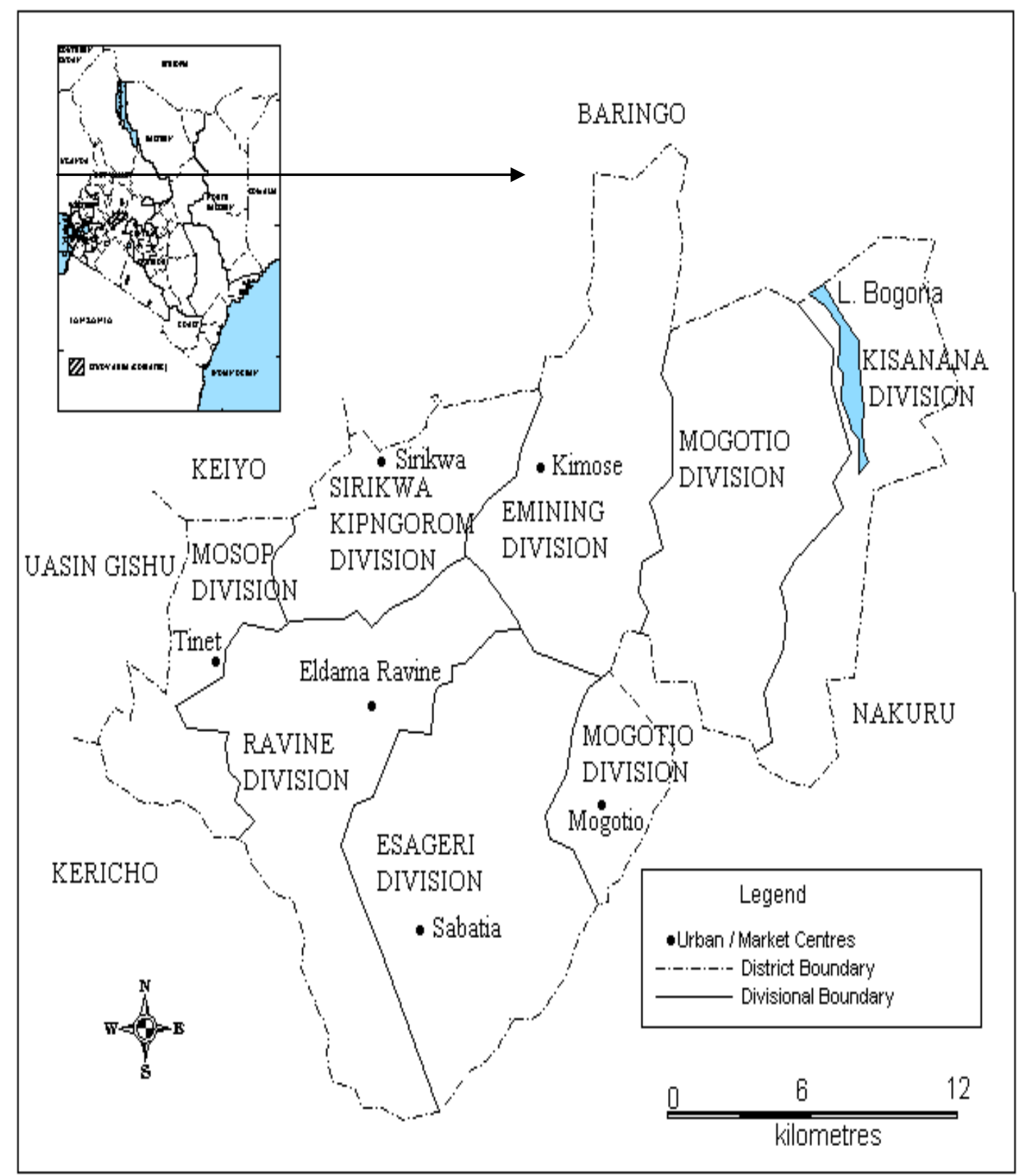

Figure 1: Map of Study Area, Koibatek District

\section{Research Methodology}

The study adopted a descriptive survey design which entailed the collection of detailed description of the four concepts in the strategy which included structure, roles, challenges and benefits. The study was based on qualitative and quantitative approach where the views on various aspects were collected through interviews and questionnaires.

The target population was 1 Officer Commanding Police Division (OCPD), 6 Officers Commanding police Stations, 1 District Administrative Police Commander (DAPC), 8 Divisional Administrative Police Commanders and 8 District Officers (DO's). Also forming the target population were 48 chiefs and 90 assistants chiefs from the districts locations and sublocations respectively, 480 community policing committees members in the locations and sub-locations and 900 of such committees members for all sub-locations. Also forming part of the target population was the community policing committee at the Divisional level who are 80 in the 8 Divisions, the DCIO and NSIS representatives, the church leaders, business community, NGO representatives and CBO representatives. From the target population, a sample of 265 respondents was picked as shown in table 1. 
Table 1: Sampling Frame

\begin{tabular}{|l|l|l|}
\hline Category & Target population & Sample \\
\hline OCPD & 1 & 1 \\
\hline OCS & 6 & 6 \\
\hline DO's & 8 & 8 \\
\hline District AP Commander & 1 & 1 \\
\hline Divisional AP Commander & 8 & 8 \\
\hline Chiefs & 48 & 24 \\
\hline Assistant Chiefs & 90 & 45 \\
\hline $\begin{array}{l}\text { DCIO and NSIS (in } \\
\text { charge) }\end{array}$ & 2 & 2 \\
\hline Division CPC & 80 & 16 \\
\hline Location CPC & 480 & 48 \\
\hline Sub-location CPC & 900 & 90 \\
\hline Church leaders & 14 & 4 \\
\hline $\begin{array}{l}\text { Business } \\
\text { leaders }\end{array}$ & 13 & 4 \\
\hline NGO representatives & 10 & 4 \\
\hline CBO representatives & 10 & 4 \\
\hline Total & 1671 & 265 \\
\hline
\end{tabular}

Stratified random sampling was used where the target population was put into various strati as per the target categories for the study. After which, the target population for the OCPD, OCS, DO'S, District AP commander and Divisional AP commander formed the sample and thus census method was used in these categories.

Fifty percent of the locations and sub-locations were included in the study and were picked using simple random sampling From the locations and sub-locations identified, three location and sub-location CPC members were purposively identified for inclusion in the study. These were chiefs/assistant chiefs, chairman and the secretary. The same case applied for District and Division CPC where the chairman and secretary were purposively selected. To get the sample for the business community committee, church leaders, NGO and CBO representatives, the chairman, secretary, vice chairman and treasurer of the committees were picked to form the sample.

Questionnaires were administered and Interviews conducted to collect the required data. Quantitative data obtained from the questionnaire were entered into statistical package for social scientists (SPSS). The data was then analyzed by descriptive statistics where frequencies and percentages were obtained and presented inform of tables. On the other hand, qualitative data were analysed using the 5 thematic steps of analysis (Jwan and Ong'ondo, 2011)

\section{RESULTS AND DISCUSSION}

\section{Availability of Community Policing Structures in Various Areas of Jurisdiction}

The findings as shown in figure 1 indicate that, there are well laid out community policing structures at all administrative levels. This was revealed as $95 \%$ of the respondents agreed to the fact that block community policing structures are in place while only a minority that is $5 \%$ disagreed to that fact. On the zone or village community policing committee, $80 \%$ of the respondents agreed to the fact that it was place while only a minority of $20 \%$ disagreed. These findings communicate that community policing committees have been established at all levels as required by the community policing manual. Therefore if there is effectiveness of community policing as a security strategy, then this could be associated with the fact that there are laid down structures while if there is any ineffectiveness then it could be associated with other factors. 


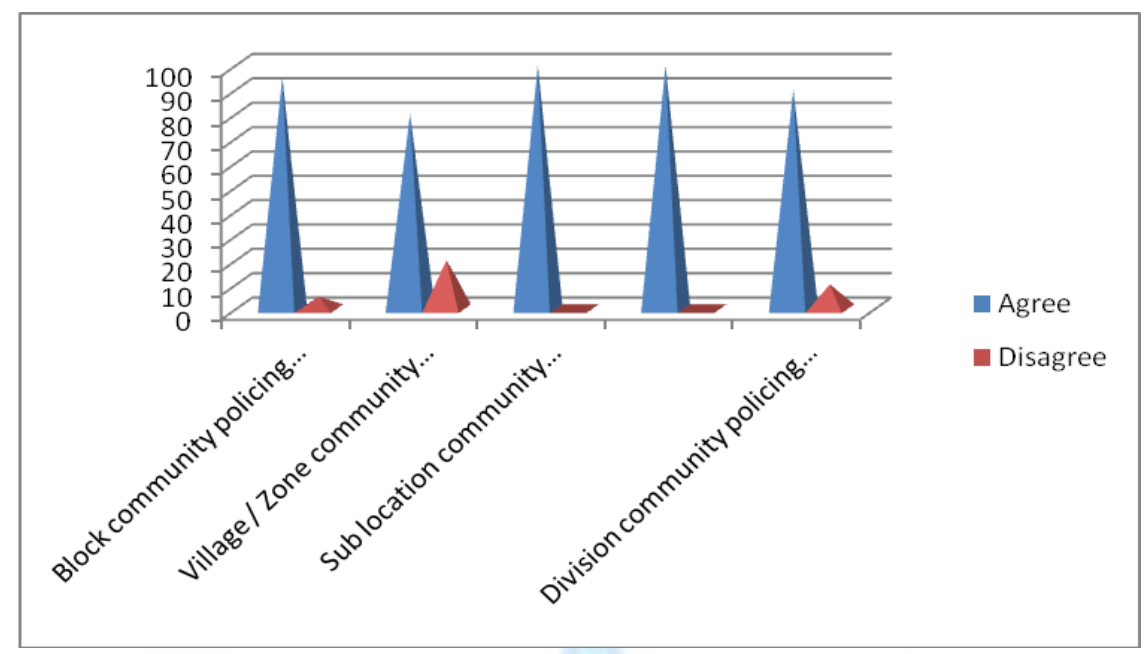

Figure 1: Availability of Community Policing Structures

\section{Source: Research Data, Author 2010}

The study further sought to find out how members to the committees were recruited. The findings as shown in the Figure 2 revealed that selection by hand picking of community policing committee members was not a popular method of recruiting the members as only a paltry $20 \%$ of the respondents agreed it is used the majority of $80 \%$ disagreed. Election was the most popular method of getting members on board to the committees as was revealed by $75 \%$ of the respondents who agreed it is commonly used, an indicator that elections were popular both in getting the members and in the choice chairman, secretary and treasurer. However, vetting and interviews to establish the integrity of the members were not done. This meant that persons of questionable and tainted character could easily be included in the community policing committees.

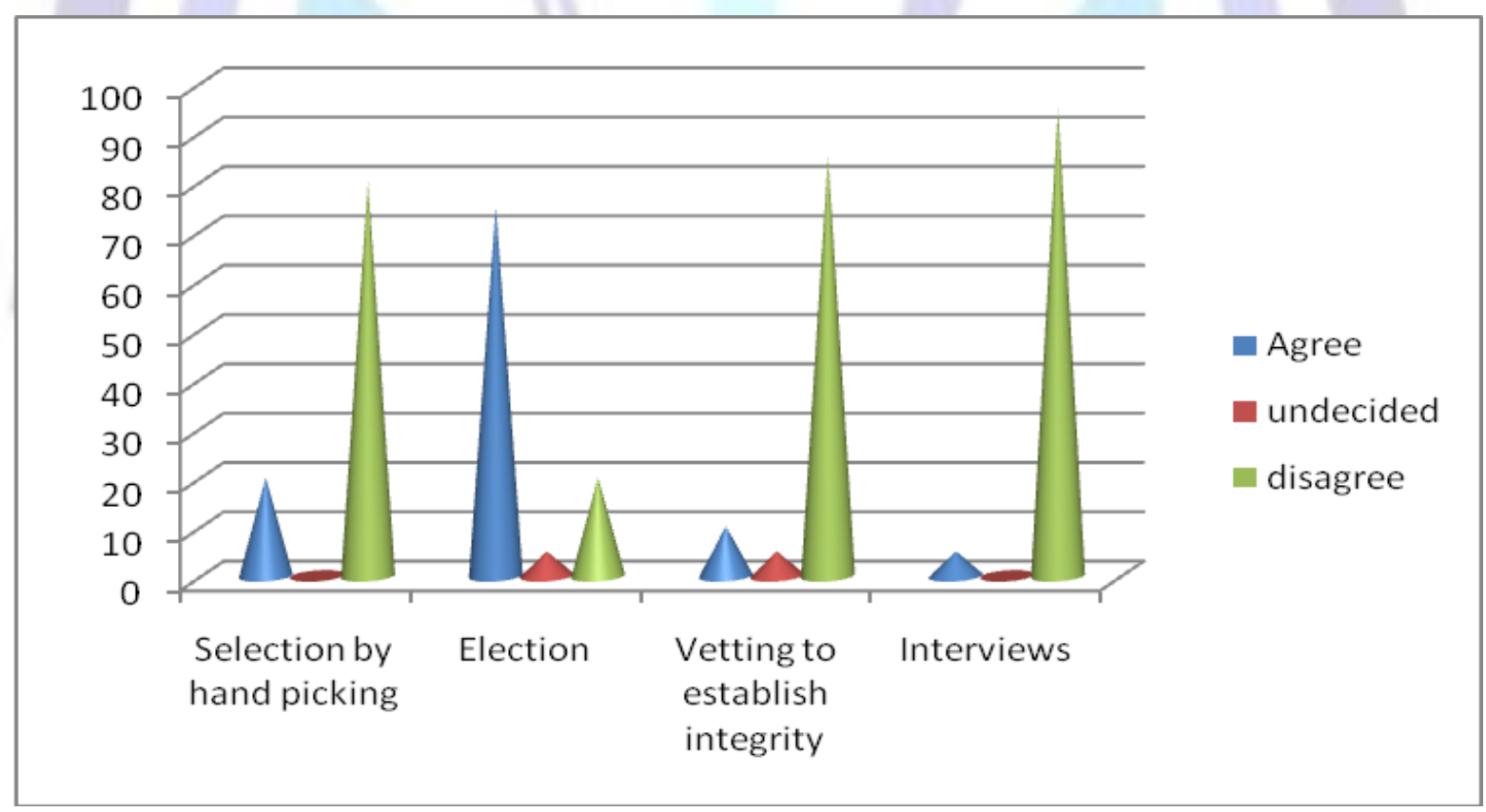

Figure 2: Criteria Used In the Getting Community Policing Committee

\section{Source: Research Data, Author 2010}




\section{The Role of Community in Community Policing}

The findings in table 2 reveal that the community has a role to play in community policing initiatives. This was exemplified by the fact that community members are required to give information to help improve on the security situation. This argument was supported by $81 \%$ of the respondents. This was an indication that the community in general had a role in community policing by providing the committee members and the police with requisite information to curb crime. In terms of knowledge and skills, the community members are free to use their skills in helping reduce insecurity. This was revealed as $90 \%$ of the respondents agreed to that fact. The experience of the community members in dealing with security matters was also a valuable input in curbing crime and criminal activities. This fact was exemplified by $95 \%$ of the respondents who agreed to that. This is a revelation that the experience of the community in security matters is necessary. The expertise of community members in matters of crime was not a requisite as revealed by the indecisiveness of the respondents as $50 \%$ agreed while $50 \%$ of the respondents disagreed that it is required. Perhaps because the expertise required in curbing crime should be offered by the police and not by the members of the community.

In case community members were called up on to carry on a particular task, sacrifice in terms of time was important as revealed by $95 \%$ of the respondents who agreed to that. Therefore, sacrifice in terms of time was required of the members of the public in order to improve the security situation not only in Koibatek but in the country as a whole.

The community in general was also required to actively participate in various activities aimed at enhancing security in their areas. This was revealed by $90 \%$ of the respondents who agreed to that fact. The common man/Wananchi is therefore required to participate in activities to improve security such as community policing barazas, Chiefs barazas and identification of criminals among others.

Table 2: The Role of the General Community in Community Policing

\begin{tabular}{|l|l|l|l|l|l|}
\hline \multirow{2}{*}{ Role } & \multicolumn{2}{l|}{ Response in Percentage } \\
\cline { 2 - 6 } & $\begin{array}{l}\text { Strongly } \\
\text { agree }\end{array}$ & Agree & undecided & Disagree & $\begin{array}{l}\text { Strongly } \\
\text { disagree }\end{array}$ \\
\hline Giving information & 20 & 61 & 0 & 10 & 9 \\
\hline Skills and Knowledge & 15 & 75 & 0 & 0 & 10 \\
\hline Experience & 40 & 55 & 0 & 5 & 0 \\
\hline Expertise & 30 & 20 & 0 & 30 & 20 \\
\hline Sacrificing time & 30 & 65 & 0 & 5 & 0 \\
\hline Active participation in various activities & 40 & 50 & 0 & 5 & 5 \\
\hline
\end{tabular}

\section{Source: Research Data, Author 2010}

\section{Benefits of Community Policing}

The findings in table 3 below indicate that there are a lot of benefits accrued from community policing. To begin with, $80 \%$ of the respondents agreed that it creates a partnership between police officers and community. The community policing concept has created a partnership and a good working relationship between the police and members of the public. Such a relationship is very conducive in fighting crime in any setting.

The findings further revealed that $95 \%$ of the respondents agreed to the fact that Community policing has sensitized both the public and the police officers on the importance of safeguarding the identity of informers. With the introduction of community policing, community members have to be assured of their own security when they provide sensitive information about criminals. For this reason the community policing has inculcated a sense to securing the identity of persons who sacrifice information to them.

It is further materialized form the study that the introduction of community policing has led to a reduction in crime. This was revealed by $90 \%$ of the respondents who were of the opinion that since the introduction of community policing, crime had drastically gone down. In fact one village elder in an interview noted;

Before introduction of community policing, there were screams every night as our village was attacked and livestock stolen. But with community policing we can sleep soundly with nothing to worry us. We don't have a reason to sleep in the same house with our livestock as we did before... (Interview with a village elder on $17^{\text {th }}$ march 2010)

In terms of recovery of stolen livestock, $59 \%$ of the respondents agreed that community policing had played a big role while $30 \%$ strongly disagreed. This implies that with community participation it has been possible to recover stolen livestock through identification of the cattle rustlers and thieves. With community participation it was possible to recover stolen items through the community policing forums and private information from members of the public to the police. This was revealed by $60 \%$ of the respondents who agreed to that fact. Community participation also led to pre-empting crime before it happened. This was opined by $65 \%$ of the respondents who agreed to that fact. Finally, $85 \%$ of the respondents agreed that Community policing helped to create a safe and secure environment for sustained socio-economic 
development. With community policing, security is enhanced thus creating a conducive environment for development as investors both local and international were encouraged to invest in the District especially in tourism ventures.

Table 3: The Benefits of Community Policing

\begin{tabular}{|c|c|c|c|c|c|}
\hline \multirow[t]{2}{*}{ Benefit } & \multicolumn{5}{|c|}{ Response in Percentage } \\
\hline & SA & A & UD & DA & SDA \\
\hline $\begin{array}{l}\text { Creates a partnership between police officers and } \\
\text { community }\end{array}$ & 25 & 55 & 0 & 5 & 15 \\
\hline $\begin{array}{l}\text { Community policing has sensitized both the public and } \\
\text { the police officers on the importance of safeguarding the } \\
\text { identity of informers }\end{array}$ & 40 & 55 & 0 & 0 & 5 \\
\hline $\begin{array}{l}\text { Since the introduction of community policing, crime has } \\
\text { drastically gone down }\end{array}$ & 50 & 40 & 0 & 5 & 5 \\
\hline It has been possible to recover stolen livestock & 25 & 35 & 0 & 10 & 30 \\
\hline $\begin{array}{l}\text { It has been possible to recover stolen items due to } \\
\text { information through the community policing forums }\end{array}$ & 35 & 25 & 0 & 20 & 20 \\
\hline $\begin{array}{l}\text { It has been possible for the community members to pre- } \\
\text { empt criminal acts }\end{array}$ & 30 & 35 & 0 & 15 & 20 \\
\hline $\begin{array}{l}\text { Community policing helps to create a safe and secure } \\
\text { environment for sustained } \\
\text { development }\end{array}$ & 30 & 55 & 0 & 15 & 0 \\
\hline
\end{tabular}

\section{Source: Research Data, Author 2010}

\section{Challenges Faced By the Community Policing Committees}

The results as shown in table 4 indicated that community policing infringing the police turf was not a challenge to community policing, as $35 \%$ of the respondents who agreed that it was a challenge, while the majority $65 \%$ disagreed. Perhaps this could be due to the good working relationship between the police and community policing committees to a point that the police do not perceive their work/activities as being affected by activities of community policing but instead playing a complementary role.

However there was perceived fear for breach of confidentiality, thus posing as a challenge as $75 \%$ of the respondents agreed to it. This indicates that in some instances, there was breach of confidentiality on members who volunteered information to the police thus causing fear. Consequently, such members of the public could fail to give the requisite security information.

The findings further revealed that inadequate information was a challenge to community policing as $80 \%$ of the respondents greed that lack of information at all levels posed a challenge to community policing while $10 \%$ disagreed. Lack of information required to pre-empt crime affected the performance community policing committees. This may have been caused by lack of communication facilities. This reduced the efficiency of the committees and the community in general in that one could identify criminals or criminal activities but be unable to communicate.

In terms of support from administrative officers, $40 \%$ agreed that it was a challenge community policing, while $60 \%$ disagreed that there is lack of support from the administration. This implies that the administrative officers were not in any way a hindrance to performance of community policing committees. This extreme response could be because of bias as some of the respondents were security officers mandated with the responsibility of getting CP committees on board and that most of the CP members especially the executive are in office with the good will the security officers. In terms of implementation of community policing forum resolution, this posed a challenge as $95 \%$ of the respondents agreed while a paltry $5 \%$ disagreed with that fact. This implies that when the community policing have their meetings where they pass resolution, these are either never effected or are effected in piece meal thus affecting motivation and morale of the members and consequently their performance.

The community policing committee members are also perceived as police spies. This was revealed by $90 \%$ of the respondents who agreed that it they are perceived as spies thus affecting their performance. This implies that the community in general does not trust the committees as it perceives its members as police spies out to gather information on various security aspects and report to them. Postponement of cases and subsequent rejection of some cases by the courts of law led to members of the public looking down upon community poling members thus affecting their performance. This was revealed by $60 \%$ of the respondents who agreed to that while $40 \%$ agreed to that.

Finally, $55 \%$ of the respondents strongly agreed to the fact that frequent transfer of senior police officers affected the performance of community policing while $45 \%$ agreed to that. As the officers got acquainted to their areas of jurisdiction, 
created a conducive working environment with the policing committees and got to identify and know the criminals, they were transferred to other areas. This acted as a challenge to community policing thus reducing its effectiveness.

Table 4: Challenges Faced by the Committees

\begin{tabular}{|l|l|l|l|l|l|}
\hline \multirow{2}{*}{ Challenge } & \multicolumn{4}{l}{ Response in Percentages } \\
\cline { 2 - 6 } & SA & A & UD & DA & SDA \\
\hline Community policing infringing the police turf & 25 & 10 & 0 & 25 & 40 \\
\hline Breach of confidentiality & 35 & 40 & 5 & 15 & 5 \\
\hline Inadequate information & 50 & 30 & 0 & 10 & 10 \\
\hline Lack of communication facilities & 20 & 80 & 0 & 0 & 0 \\
\hline Lack of Support for CP efforts & 10 & 0 & 0 & 30 & 60 \\
\hline $\begin{array}{l}\text { Lack of implementation of resolution made at } \\
\text { CP Forums }\end{array}$ & 40 & 55 & 0 & 0 & 5 \\
\hline $\begin{array}{l}\text { Community policing members believed to be } \\
\text { police spies }\end{array}$ & 50 & 40 & 10 & 0 & 0 \\
\hline Courts cases & 60 & 40 & 0 & 0 & 0 \\
\hline Frequent transfers of police officers & 55 & 45 & 0 & 0 & 0 \\
\hline
\end{tabular}

\section{Source: Research Data, Author 2010 CONCLUSIONS}

Based on the findings of the study, the following conclusions were drawn:

That community policing as a strategy for curbing insecurity is a noble idea and has been well practiced. The outcome being that crime rate notably reduced. There are quite a number of benefits to the entire community from the concept. Therefore judging from the results obtained, the study concluded that community policing has been effective and can have a positive effect on the community.

The roles played by all the stakeholders either voluntarily or through formal responsibilities indicate that there is effectiveness in the community policing strategy. However, some CP members are disillusioned due to lack of remuneration whereas some joined CP hoping to make a living out of it. Therefore, some CP members have been suspected to extort protection money from law breakers.

Pertaining to the structures all participants involved are aware of the channel to follow in safeguarding security. However, there are many challenges faced by different persons involved in community policing such as manipulation of charges and lack of proper communication facilities among others.

The Community Policing forum members have difficulty in getting to and from police stations due to lack of transport means, poor roads especially when it rains, lack of electricity to charge mobile phones for those who have them and even lack of airtime to call the police when need arises. Lack of resources threatens the process of community involvement and can also demoralize police officers and make them decline the additional demands Community Policing places on them.

\section{RECOMMENDATIONS}

There is need to have a CP structure at the Province and National level. This will give CP more clout and visibility as it will be easier to reach out to policy makers. Further, security agents must constantly supervise CP to ensure that members do not go overboard and transform themselves into vigilantes who take the law into their hands.

In the selection of community policing committee members, there is need to do proper vetting of these members so as to ensure that only the best elements with the requisite skills and experiences form part of the committees. This will make the committees effective.

There is urgent need to capacity build members of CP committees so as to enable them understand their roles better. Capacity building should also include provision of equipments and the requisite training for all CP members.

There is need to market Community Policing in the media. It can play the key role through wide dissemination of information. Most people form their impression of crime and the justice system from newspapers, television and radio rather than from direct exposure (Chermark et al 1995). Therefore, the police must seek to use the media to involve community members in crime prevention and problem solving. 
The availability of the basic resources required by the police and the community policing committees is critical. Basic resources refer to functioning vehicles, equipment and infrastructure appropriate to the topography of the area and also a means to gather and analyze intelligence.

The police and Community Policing forums must be able to develop an active relationship with other role players with the goal of jointly contributing to crime reduction. This is the icing on the cake for Community Policing. In Koibatek, this would be an ideal way of penetrating the different ethnic communities and engage them through such partnerships. With such a mechanism in place, community policing resolutions will implemented with a lot of ease.

\section{BIBLIOGRAPHY}

1. Mwambe, j. (2007). Kenya; Sungu Sungu: Three Kisii Districts In Fear. Retrieved from

a. $\quad$ www.allafrica.com on $27^{\text {th }}$ March 2007

2. Rotich, A. (2007). Sungu Sungu Lynches Five Relatives In Kisii District. Retrieved from

a. $\quad$ www.allafrica.com on $20^{\text {th }}$ June 2007

3. Kwalia, J and Ng'etich, P (2007). Six gunned down near District headquarters. Daily

a. Nation, April 3, pg 6

4. Mathias Ringa (2008). Leaders preach peace to rescue tourism industry, Daily Nation,

a. February 8, Pg 19.

5. Beuttah O (2007). Sungu Sungu - Three Kisii Districts in fear over bizzare killings, East

a. African standard, July $23, \mathrm{Pg} 10$

6. Nyasato, R (2007) Sungu Sungu gang lynches five relatives. East African standard

a. August 23, Pg 10

7. GOK (2004) Community Policing Manual, Government printers: Nairobi

8. Kenya vision 2030, (2007): Security Peace Building and Conflict Management;

a. Government Printer; Nairobi.

9. GOK (2007). National Policy on Community Policing Draft 2; Report by National Task

a. Force On Police Reforms On 23 ${ }^{\text {rd }}$ May, 2007, Government printers: Nairobi.

10. Okoko. J.(2007) Report by Kenya National Focal Point On taking Community Policing

a. Agenda Forward: Progress and Roll Out Plan. Retrieved from www.focalpint .com on $22^{\text {nd }}$ June 2007

11. Sang, F.(2007): Regional Centre On small arms report on proliferation of small arms

a. and weapons in Kenya. Retrieved from www.rcsmp.com on $25^{\text {th }}$ August 2007

12. Okwembah, D and Raguma, D. (2007) 100,000 reasons to be afraid, Sunday Nation,

a. March $11 \mathrm{Pg} 15$.

13. Nation Team (2007). Another village mourns as Mungiki terror gang beheads matatu

a. crew, Sunday Nation, June 3, Pg 17

14. Sunday Nation correspondent (2007). Terror group associated with politicians, Sunday

a. Nation, June $10, \operatorname{Pg} 12$

15. Wabala, D (2007). Grenade attacks worry police, Sunday Nation, October 21, Pg 15

16. GOK (2004) H.E. The President's speech on the Official launch of community policing at Ruai Police Station, Nairobi, Retrived from www.statehousekenya.go.ke, on April 27, 2004. 